National and Global Petroleum Assessment

\title{
Assessment of Undiscovered Continuous Oil Resources in the Bakken and Three Forks Formations of the Williston Basin Province, North Dakota and Montana, 2021
}

Using a geology-based assessment methodology, the U.S. Geological Survey estimated undiscovered, technically recoverable mean resources of 4.3 billion barrels of oil and 4.9 trillion cubic feet of gas (associated) in the Bakken and Three Forks Formations of the Williston Basin Province, North Dakota and Montana.

\section{Introduction}

The U.S. Geological Survey (USGS) completed a quantitative, geology-based assessment of undiscovered, technically recoverable continuous (unconventional) oil resources in the Upper Devonian to Lower Mississippian Bakken Formation and Upper Devonian Three

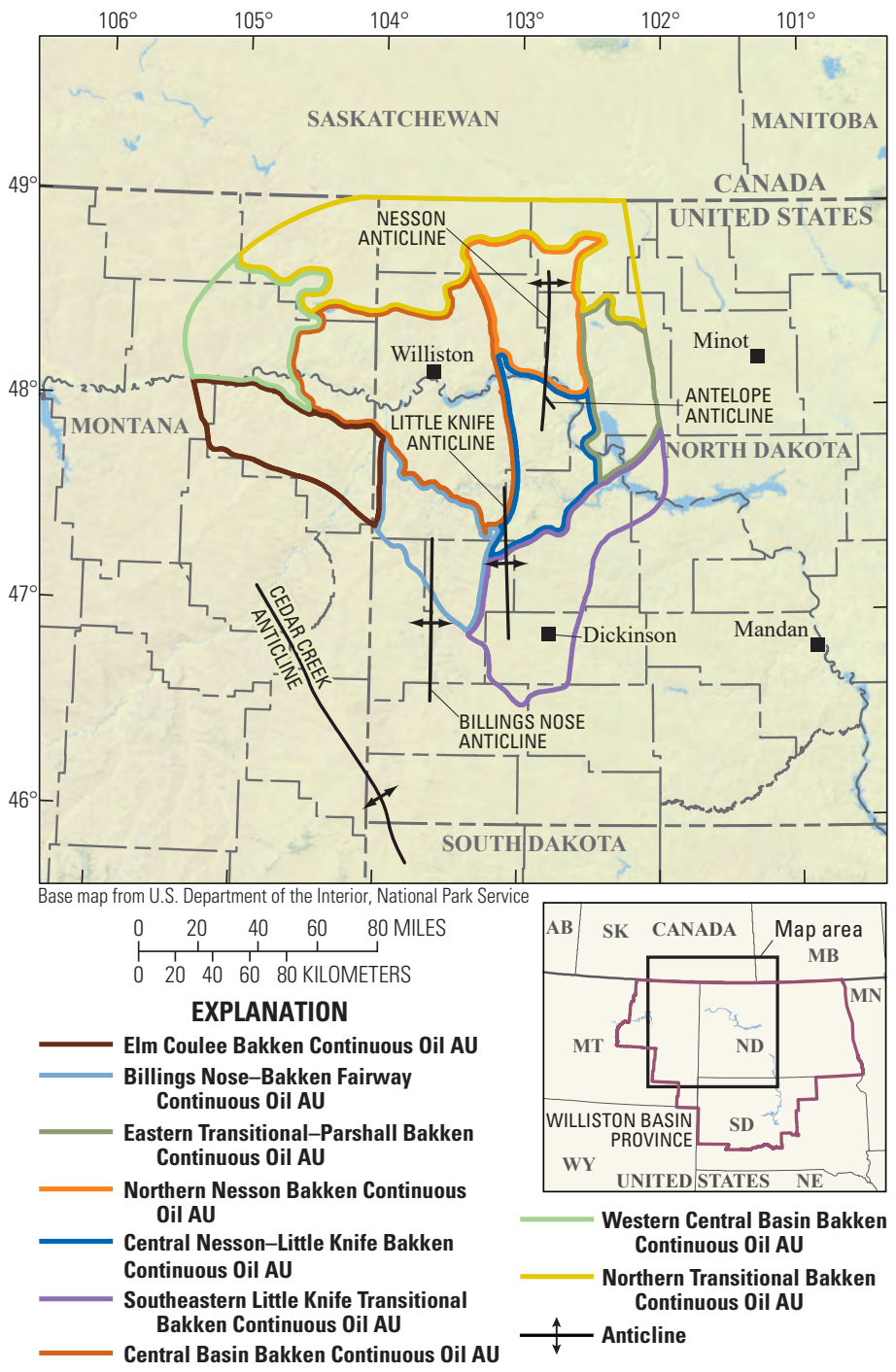

Figure 1. Map showing the Bakken Formation assessment units (AUs), North Dakota and Montana. Major structural features are also shown. Inset map (bottom right) shows the Williston Basin Province boundary.
Forks Formation (Nesheim, 2019) within the U.S. part of the Williston Basin Province of North Dakota and Montana (figs. 1 and 2; tables 1 and 2). The Bakken Formation was previously assessed by the USGS in both 2008 and 2013, and the Three Forks Formation was initially assessed in 2013 (Pollastro and others, 2008; Gaswirth and others, 2013). Since the 2013 assessment, more than 6,400 additional wells have been drilled in the Bakken Formation, and approximately 4,100 wells have been drilled in the underlying Three Forks Formation (IHS Markit $\left.{ }^{\circ}, 2021\right)$. To date, more than 17,500 total wells have been drilled into the Bakken and Three Forks Formations, and approximately 4 billion barrels of oil have been produced from these units (IHS Markit ${ }^{2}, 2021$ ).

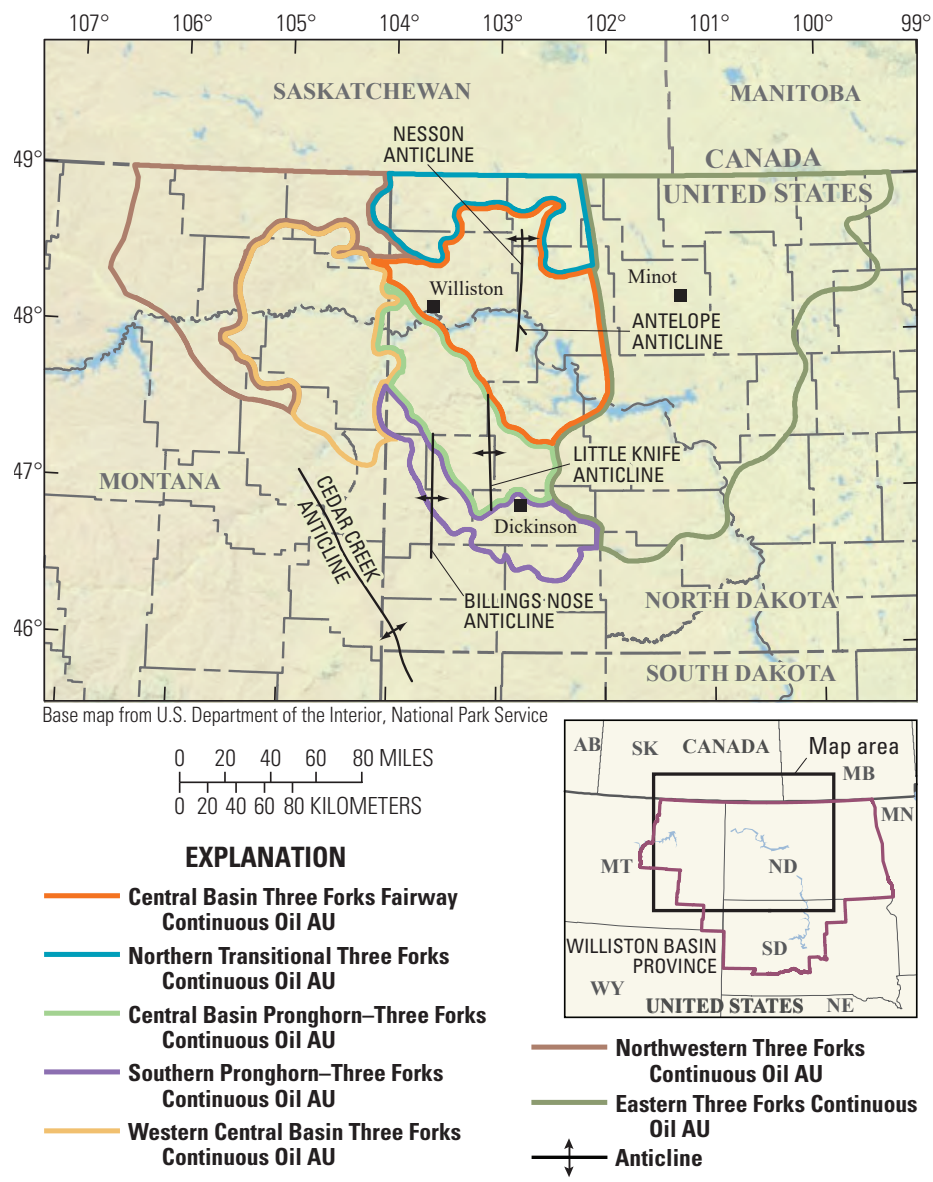

Figure 2. Map showing the Three Forks Formation assessment units (AUs) North Dakota and Montana. Major structural features are also shown. Inset map (bottom right) shows the Williston Basin Province boundary. 
Table 1. Key input data for nine continuous oil assessment units in the Bakken Formation of the Williston Basin Province, North Dakota and Montana.

[The average EUR input is the minimum, median, maximum, and calculated mean. Gray shading indicates not applicable. AU, assessment unit; \%, percent; EUR, estimated ultimate recovery; MMBO, million barrels of oil]

\begin{tabular}{|c|c|c|c|c|c|c|c|c|}
\hline \multirow{2}{*}{$\begin{array}{l}\text { Assessment input data- } \\
\text { Continuous AUs }\end{array}$} & \multicolumn{3}{|c|}{ Elm Coulee Bakken Continuous Oil } & \multicolumn{5}{|c|}{ Billings Nose-Bakken Fairway Continuous Oil } \\
\hline & Minimum & Mode & Maximum & Calculated mean & Minimum & Mode & Maximum & Calculated mean \\
\hline Potential production area of AU (acres) & 1,000 & 450,000 & 994,000 & 481,667 & 1,000 & 300,000 & 765,000 & 355,333 \\
\hline Average drainage area of wells (acres) & 280 & 320 & 380 & 326.7 & 240 & 280 & 320 & 280 \\
\hline Success ratio (\%) & 85 & 90 & 99 & 91.3 & 70 & 85 & 95 & 83.3 \\
\hline Untested area $(\%)$ & 60 & 65 & 70 & 65 & 80 & 85 & 90 & 85 \\
\hline Average EUR (MMBO) & 0.15 & 0.18 & 0.22 & 0.182 & 0.04 & 0.08 & 0.13 & 0.082 \\
\hline AU probability & 1.0 & & & & 1.0 & & & \\
\hline \multirow{2}{*}{$\begin{array}{l}\text { Assessment input data- } \\
\text { Continuous AUs }\end{array}$} & \multicolumn{3}{|c|}{ Eastern Transitional-Parshall Bakken Continuous 0il } & \multicolumn{5}{|c|}{ Northern Nesson Bakken Continuous Oil } \\
\hline & Minimum & Mode & Maximum & Calculated mean & Minimum & Mode & Maximum & Calculated mean \\
\hline Potential production area of AU (acres) & 1,000 & 600,000 & 705,000 & 435,333 & 1,000 & 600,000 & $1,015,000$ & 538,667 \\
\hline Average drainage area of wells (acres) & 280 & 320 & 380 & 326.7 & 280 & 320 & 380 & 326.7 \\
\hline Success ratio (\%) & 95 & 98 & 99 & 97.3 & 85 & 90 & 99 & 91.3 \\
\hline Untested area $(\%)$ & 25 & 30 & 35 & 30 & 50 & 55 & 60 & 55 \\
\hline Average EUR (MMBO) & 0.36 & 0.4 & 0.44 & 0.401 & 0.2 & 0.26 & 0.3 & 0.261 \\
\hline AU probability & 1.0 & & & & 1.0 & & & \\
\hline \multirow{2}{*}{$\begin{array}{l}\text { Assessment input data- } \\
\text { Continuous AUs }\end{array}$} & \multicolumn{3}{|c|}{ Central Nesson-Little Knife Bakken Continuous 0il } & \multicolumn{5}{|c|}{ Southeastern Little Knife Transitional Bakken Continuous 0il } \\
\hline & Minimum & Mode & Maximum & Calculated mean & Minimum & Mode & Maximum & Calculated mean \\
\hline Potential production area of AU (acres) & 1,000 & 700,000 & 880,000 & 529,667 & 1,000 & 500,000 & $1,433,000$ & 644,667 \\
\hline Average drainage area of wells (acres) & 280 & 320 & 380 & 326.7 & 240 & 280 & 320 & 280 \\
\hline Success ratio $(\%)$ & 97 & 98 & 99 & 98 & 70 & 85 & 95 & 83.3 \\
\hline Untested area (\%) & 5 & 10 & 15 & 10 & 80 & 85 & 90 & 85 \\
\hline Average EUR (MMBO) & 0.48 & 0.5 & 0.52 & 0.501 & 0.15 & 0.2 & 0.25 & 0.202 \\
\hline AU probability & 1.0 & & & & 1.0 & & & \\
\hline \multirow{2}{*}{$\begin{array}{l}\text { Assessment input data- } \\
\text { Continuous AUs }\end{array}$} & \multicolumn{3}{|c|}{ Central Basin Bakken Continuous 0il } & \multicolumn{5}{|c|}{ Western Central Basin Bakken Continuous Oil } \\
\hline & Minimum & Mode & Maximum & Calculated mean & Minimum & Mode & Maximum & Calculated mean \\
\hline Potential production area of AU (acres) & 1,000 & $1,800,000$ & $2,455,000$ & $1,418,667$ & 1,000 & 300,000 & 909,000 & 403,333 \\
\hline Average drainage area of wells (acres) & 280 & 320 & 380 & 326.7 & 240 & 280 & 320 & 280 \\
\hline Success ratio (\%) & 80 & 95 & 99 & 91.3 & 30 & 50 & 90 & 56.7 \\
\hline Untested area (\%) & 45 & 50 & 55 & 50 & 97 & 98 & 99.5 & 98.2 \\
\hline Average EUR (MMBO) & 0.22 & 0.28 & 0.35 & 0.283 & 0.02 & 0.05 & 0.1 & 0.052 \\
\hline AU probability & 1.0 & & & & 1.0 & & & \\
\hline \multirow{2}{*}{$\begin{array}{l}\text { Assessment input data- } \\
\text { Continuous AUs }\end{array}$} & \multicolumn{4}{|c|}{ Northern Transitional Bakken Continuous Oil } & & & & \\
\hline & Minimum & Mode & Maximum & Calculated mean & & & & \\
\hline Potential production area of AU (acres) & 1,000 & 700,000 & $2,067,000$ & 922,667 & & & & \\
\hline Average drainage area of wells (acres) & 240 & 280 & 320 & 280 & & & & \\
\hline Success ratio (\%) & 70 & 85 & 95 & 83.3 & & & & \\
\hline Untested area (\%) & 85 & 90 & 95 & 90 & & & & \\
\hline Average EUR (MMBO) & 0.08 & 0.13 & 0.19 & 0.132 & & & & \\
\hline AU probability & 1.0 & & & & & & & \\
\hline
\end{tabular}

\section{Geologic Summary}

The Bakken and Three Forks Formations are part of the Bakken Total Petroleum System (TPS), which includes strata from the Upper Devonian Three Forks Formation, Upper Devonian to Lower Mississippian Bakken Formation, and the lowermost part of the Lower Mississippian Lodgepole Formation within the Williston Basin (Gaswirth and Marra, 2015). The Williston Basin is an intracratonic basin that extends across areas of Montana, South Dakota, and North Dakota in the United States, and the provinces of Saskatchewan and Manitoba in Canada (Gaswirth and Marra, 2015; Sonnenberg, 2018).

The Three Forks Formation overlies carbonates of the Upper Devonian Birdbear Formation and is unconformably overlain by transgressive deposits of the Bakken Formation. The Three Forks includes dolomitic shale, siltstone, and dolostone, which suggest deposition within hypersaline marine, subtidal, and intertidal environments. Anhydrite nodules are common within lower sections of the Three Forks Formation. The Three Forks is commonly divided into informal lower, middle, and upper intervals or into four informal benches, a distinction typically used by industry (LeFever and others, 2011; Gaswirth and Marra, 2015; Sonnenberg, 2018; Nesheim, 2019).

The Bakken Formation consists of four units: (1) the Pronghorn Member, (2) lower shale member, (3) middle member, and (4) upper shale member (LeFever and others, 2011). The Pronghorn Member exhibits a fining-upward trend composed of sandstone, siltstone, dolomitic mudstone, shale, and limestone, and forms the first transgressive unit of the Bakken Formation. The Pronghorn is limited in extent across the basin and was assessed with the Three Forks Formation because of fluid communication between reservoirs. The two informal 
Table 2. Key input data for six continuous oil assessment units in the Three Forks Formation of the Williston Basin Province, North Dakota and Montana.

[The average EUR input is the minimum, median, maximum, and calculated mean. Gray shading indicates not applicable. AU, assessment unit; \%, percent; EUR, estimated ultimate recovery; MMBO, million barrels of oil]

\begin{tabular}{|c|c|c|c|c|c|c|c|c|}
\hline \multirow{2}{*}{$\begin{array}{l}\text { Assessment input data- } \\
\text { Continuous AUs }\end{array}$} & \multicolumn{4}{|c|}{ Central Basin Three Forks Fairway Continuous Oil } & \multicolumn{4}{|c|}{ Northern Transitional Three Forks Continuous Oil } \\
\hline & Minimum & Mode & Maximum & Calculated mean & Minimum & Mode & Maximum & Calculated mean \\
\hline Potential production area of AU (acres) & 1,000 & $2,500,000$ & $3,908,500$ & $2,136,500$ & 1,000 & 500,000 & $1,448,000$ & 649,667 \\
\hline Average drainage area of wells (acres) & 280 & 320 & 380 & 326.7 & 240 & 280 & 320 & 280 \\
\hline Success ratio $(\%)$ & 90 & 95 & 99 & 94.7 & 70 & 85 & 95 & 83.3 \\
\hline Untested area $(\%)$ & 60 & 65 & 70 & 65 & 85 & 90 & 95 & 90 \\
\hline Average EUR (MMBO) & 0.3 & 0.33 & 0.38 & 0.332 & 0.1 & 0.13 & 0.18 & 0.132 \\
\hline AU probability & 1.0 & & & & 1.0 & & & \\
\hline \multirow{2}{*}{$\begin{array}{l}\text { Assessment input data- } \\
\text { Continuous AUs }\end{array}$} & \multicolumn{4}{|c|}{ Central Basin Pronghorn-Three Forks Continuous 0il } & \multicolumn{4}{|c|}{ Southern Pronghorn-Three Forks Continuous Oil } \\
\hline & Minimum & Mode & Maximum & Calculated mean & Minimum & Mode & Maximum & Calculated mean \\
\hline Potential production area of AU (acres) & 1,000 & $1,300,000$ & $2,275,000$ & $1,192,000$ & 1,000 & 400,000 & $1,407,300$ & 602,767 \\
\hline Average drainage area of wells (acres) & 280 & 320 & 380 & 326.7 & 240 & 280 & 320 & 280 \\
\hline Success ratio $(\%)$ & 80 & 90 & 95 & 88.3 & 70 & 85 & 95 & 83.3 \\
\hline Untested area $(\%)$ & 85 & 90 & 95 & 90 & 95 & 98 & 99 & 97.3 \\
\hline Average EUR (MMBO) & 0.12 & 0.16 & 0.2 & 0.161 & 0.1 & 0.14 & 0.18 & 0.141 \\
\hline AU probability & 1.0 & & & & 1.0 & & & \\
\hline \multirow{2}{*}{$\begin{array}{c}\text { Assessment input data- } \\
\text { Continuous AUs }\end{array}$} & \multicolumn{4}{|c|}{ Western Central Basin Three Forks Continuous Oil } & \multicolumn{4}{|c|}{ Northwestern Three Forks Continuous Oil } \\
\hline & Minimum & Mode & Maximum & Calculated mean & Minimum & Mode & Maximum & Calculated mean \\
\hline Potential production area of AU (acres) & 1,000 & 300,000 & $3,160,000$ & $1,153,667$ & 1,000 & 100,000 & $3,915,000$ & $1,338,667$ \\
\hline Average drainage area of wells (acres) & 240 & 280 & 320 & 280 & 240 & 280 & 320 & 280 \\
\hline Success ratio $(\%)$ & 30 & 50 & 90 & 56.7 & 10 & 30 & 50 & 30 \\
\hline Untested area (\%) & 98 & 99 & 100 & 99 & 100 & 100 & 100 & 100 \\
\hline Average EUR (MMBO) & 0.016 & 0.02 & 0.06 & 0.022 & 0.004 & 0.006 & 0.03 & 0.007 \\
\hline AU probability & 1.0 & & & & 0.5 & & & \\
\hline
\end{tabular}

upper and lower shale members are organic rich and form the hydrocarbon source intervals for the Bakken TPS. Oil generated from these source units has locally migrated into the informal middle member of the Bakken, the Pronghorn Member of the Bakken, and dolomitized intervals of the underlying Three Forks Formation. The middle member of the Bakken is the main horizontal drilling target within the Bakken Formation and is composed of sandstone, siltstone, dolomite, and mudstone deposited within a shallow water environment during sea level regression. The upper shale member has the greatest regional extent and forms the outermost boundary of the continuous resource assessment units (Pollastro and others, 2012; Gaswirth and Marra, 2015).

The Three Forks is primarily charged by the overlying lower shale member of the Bakken Formation, where areas of increased shale thickness, higher thermal maturity, and overpressure facilitate local migration into intervals of the Three Forks Formation (Nesheim, 2019). Horizontal drilling primarily targets the upper interval of the Three Forks Formation because of its proximity to the overlying source rock and generally higher oil saturations than lower intervals of the formation. Middle and lower strata of the Three Forks have also been tested and drilled with variable results (LeFever and others, 2011; Gaswirth and Marra, 2015; Nesheim, 2019).

\section{Assessment Units}

A total of nine continuous Bakken and seven continuous Three Forks assessment units (AUs) were defined (figs. 1 and 2, respectively). Assessment unit boundaries were defined based on thermal maturity boundaries, structural features, formation extents and thickness trends, and variability in water saturations. Key input data used to assess the Bakken and Three Forks Formations are listed in tables 1 and 2 , respectively.

\section{Undiscovered Resources Summary}

The USGS quantitatively assessed 15 AUs for undiscovered, technically recoverable continuous oil, gas, and natural gas liquid resources for the Bakken and Three Forks Formations in the Williston Basin of North Dakota and Montana (table 3). The fully risked estimated mean totals are 4,288 million barrels of oil (MMBO) with an F95-F5 fractile range from 1,328 to 7,302 MMBO; 4,872 billion cubic feet of gas (BCFG) with an F95-F5 range from 1,522 to 8,232 BCFG; and 417 million barrels of natural gas liquids (MMBNGL) with an F95-F5 range from 132 to 700 MMBNGL. The Eastern Three Forks Continuous Oil AU was not quantitatively assessed.

\section{References Cited}

Gaswirth, S.B., and Marra, K.R., 2015, U.S. Geological Survey 2013 assessment of undiscovered resources in the Bakken and Three Forks Formations of the U.S. Williston Basin Province: The American Association of Petroleum Geologists Bulletin, v. 99, no. 4, p. 639-660. [Also available at https://doi.org/10.1306/08131414051.]

Gaswirth, S.B., Marra, K.R., Cook, T.A., Charpentier, R.R., Gautier, D.L., Higley, D.K., Klett, T.R., Lewan, M.D., Lillis, P.G., Schenk, C.J., Tennyson, M.E., and Whidden, K.J., 2013, Assessment of undiscovered oil resources in the Bakken and Three Forks Formations, Williston Basin Province, Montana, North Dakota, and South Dakota, 2013: U.S. Geological Survey Fact Sheet 2013-3013, 4 p., accessed November 24, 2021, at https://doi.org/10.3133/fs20133013.

IHS Markit ${ }^{\circledR}, 2021$, Enerdeq ${ }^{\mathrm{TM}}$ US well history and production database: Englewood, Colo., IHS Markit ${ }^{\circledR}$, accessed October 15, 2021, at https://www.ihsmarkit.com. [Available from IHS Markit, 15 Inverness Way East, Englewood, CO 80112.] 
Table 3. Results for 15 continuous assessment units in the Bakken and Three Forks Formations of the Williston Basin Province, North Dakota and Montana.

[Results shown are fully risked estimates. F95 represents a 95-percent chance of at least the amount tabulated; other fractiles are defined similarly. Gray shading indicates not applicable. MMBO, million barrels of oil; BCFG, billion cubic feet of gas; NGL, natural gas liquids; MMBNGL, million barrels of natural gas liquids]

\begin{tabular}{|c|c|c|c|c|c|c|c|c|c|c|c|c|c|c|}
\hline \multirow{3}{*}{ Total petroleum system and assessment units (AUs) } & \multirow{3}{*}{$\begin{array}{c}\text { AU } \\
\text { prob- } \\
\text { ability }\end{array}$} & \multirow{3}{*}{$\begin{array}{c}\text { Accu- } \\
\text { mulation } \\
\text { type }\end{array}$} & \multicolumn{12}{|c|}{ Total undiscovered resources } \\
\hline & & & \multicolumn{4}{|c|}{ Oil (MMBO) } & \multicolumn{4}{|c|}{ Gas (BCFG) } & \multicolumn{4}{|c|}{ NGL (MMBNGL) } \\
\hline & & & F95 & F50 & F5 & Mean & F95 & F50 & F5 & Mean & F95 & F50 & F5 & Mean \\
\hline \multicolumn{15}{|c|}{ Bakken Total Petroleum System } \\
\hline Elm Coulee Bakken Continuous Oil & 1 & Oil & 49 & 156 & 276 & 159 & 49 & 156 & 278 & 159 & 4 & 13 & 24 & 14 \\
\hline Billings Nose-Bakken Fairway Continuous Oil & 1 & Oil & 22 & 70 & 137 & 74 & 30 & 98 & 192 & 103 & 3 & 8 & 16 & 9 \\
\hline Eastern Transitional-Parshall Bakken Continuous Oil & 1 & Oil & 52 & 164 & 240 & 157 & 41 & 130 & 194 & 125 & 4 & 11 & 17 & 11 \\
\hline Northern Nesson Bakken Continuous Oil & 1 & Oil & 69 & 220 & 354 & 216 & 96 & 307 & 497 & 303 & 8 & 26 & 42 & 26 \\
\hline Central Nesson-Little Knife Bakken Continuous Oil & 1 & Oil & 25 & 80 & 138 & 80 & 35 & 111 & 193 & 112 & 3 & 9 & 16 & 10 \\
\hline Southeastern Little Knife Transitional Bakken Continuous Oil & 1 & Oil & 95 & 313 & 608 & 330 & 57 & 187 & 368 & 198 & 5 & 16 & 31 & 17 \\
\hline Central Basin Bakken Continuous Oil & 1 & Oil & 185 & 581 & 882 & 561 & 221 & 695 & 1,062 & 673 & 19 & 59 & 90 & 57 \\
\hline Western Central Basin Bakken Continuous Oil & 1 & Oil & 11 & 37 & 88 & 42 & 11 & 37 & 89 & 42 & 1 & 3 & 8 & 4 \\
\hline Northern Transitional Bakken Continuous Oil & 1 & Oil & 93 & 308 & 614 & 327 & 93 & 308 & 616 & 327 & 8 & 26 & 53 & 28 \\
\hline Total Bakken undiscovered continuous oil resources & & & 601 & 1,929 & 3,337 & 1,946 & 633 & 2,029 & 3,489 & 2,042 & 55 & 171 & 297 & 176 \\
\hline Central Basin Three Forks Fairway Continuous Oil & 1 & Oil & 432 & 1,378 & 2,146 & 1,340 & 562 & 1,789 & 2,797 & 1,742 & 48 & 152 & 238 & 148 \\
\hline Northern Transitional Three Forks Continuous Oil & 1 & Oil & 66 & 218 & 427 & 230 & 66 & 218 & 428 & 230 & 6 & 19 & 36 & 20 \\
\hline Central Basin Pronghorn-Three Forks Continuous Oil & 1 & Oil & 152 & 474 & 774 & 469 & 198 & 616 & 1,010 & 610 & 17 & 52 & 86 & 52 \\
\hline Southern Pronghorn-Three Forks Continuous Oil & 1 & Oil & 69 & 231 & 474 & 247 & 55 & 184 & 380 & 198 & 5 & 16 & 32 & 17 \\
\hline Western Central Basin Three Forks Continuous Oil & 1 & Oil & 8 & 42 & 122 & 51 & 8 & 38 & 111 & 46 & 1 & 3 & 9 & 4 \\
\hline Northwestern Three Forks Continuous Oil & 0.5 & Oil & 0 & 0 & 22 & 5 & 0 & 0 & 17 & 4 & 0 & 0 & 2 & 0 \\
\hline Eastern Three Forks Continuous Oil & & Oil & \multicolumn{12}{|c|}{ Not quantitatively assessed } \\
\hline Total Three Forks undiscovered continuous oil resources & & & 727 & 2,343 & 3,965 & 2,342 & 889 & 2,845 & 4,743 & 2,830 & 77 & 242 & 403 & 241 \\
\hline $\begin{array}{l}\text { Total Bakken-Three Forks undiscovered continuous oil } \\
\text { resources }\end{array}$ & & & 1,328 & 4,272 & 7,302 & 4,288 & 1,522 & 4,874 & 8,232 & 4,872 & 132 & 413 & 700 & 417 \\
\hline
\end{tabular}

LeFever, J.A., LeFever, R.D., and Nordeng, S.H., 2011, Revised nomenclature for the Bakken Formation (Mississippian-Devonian), North Dakota, in Robinson, J.W., LeFever, J.A., and Gaswirth, S.B., eds., The Bakken-Three Forks petroleum system in the Williston Basin Guidebook: Denver, Colo., Rocky Mountain Association of Geologists, 1 CD-ROM, p. 11-26.

Nesheim, T.O., 2019, Examination of downward hydrocarbon charge within the Bakken-Three Forks petroleum system-Williston Basin, North America: Marine and Petroleum Geology, v. 104, p. 346-360. [Also available at https://doi.org/10.1016/j.marpetgeo.2019.03.016.]

Pollastro, R.M., Cook, T.M., Roberts, L.N.R., Schenk, C.J., Lewan, M.J., Anna, L.O., Gaswirth, S.B., Lillis, P.G., Klett, T.R., and Charpentier, R.R., 2008, Assessment of undiscovered oil resources in the DevonianMississippian Bakken Formation, Williston Basin Province, Montana and North Dakota: U.S. Geological Survey Fact Sheet 2008-3021, 2 p. [Also available at https://doi.org/10.3133/fs20083021.]
Pollastro, R.M., Roberts, L.N.R., and Cook, T.A., 2012, Geologic model for the assessment of technically recoverable oil in the DevonianMississippian Bakken Formation, Williston Basin, in Breyer, J.A., ed., Shale reservoirs - Giant resources for the 21st century: American Association of Petroleum Geologists Memoir 97, p. 205-257. [Also available at https://doi.org/10.1306/13321469M97948.]

Sonnenberg, S.A., 2018, Sequence stratigraphy of the Bakken and Three Forks Formations, Williston Basin, USA, in Hart, B., Rosen, N.C., West, D., D’Agostino, A., Messina, C., Hoffman, M., and Wild, R., eds., Sequence stratigraphy - The future defined-Gulf Coast Section SEPM Society for Sedimentary Geology Foundation, 36th Annual GCSSEPM Foundation Perkins-Rosen Research Conference, Houston, Tex., December 4-5, 2017, Proceedings: Gulf Coast Section SEPM Society for Sedimentary Geology, v. 36, 273 p., accessed October 15, 2021, at https://doi.org/10.5724/gcs.17.

\section{For More Information}

Assessment and methodology information can be accessed at the USGS Energy Resources Program website at https:/www.usgs.gov/energy-and-minerals/energy-resources-program/.

\section{Bakken and Three Forks Formations Assessment Team}

Kristen R. Marra, Tracey J. Mercier, Sarah E. Gelman, Christopher J. Schenk, Cheryl A. Woodall, Andrea D. Cicero, Ronald M. Drake II, Geoffrey S. Ellis, Thomas M. Finn, Michael H. Gardner, Jane S. Hearon, Benjamin G. Johnson, Jenny H. Lagesse, Phuong A. Le, Heidi M. Leathers-Miller, Kira K. Timm, Scott S. Young 